\title{
PRETTIESISKUMA IZPRATNES PROBLEMĀTIKA KRIMINĀLTIESĪBĀS
}

\section{PROBLEMS OF UNDERSTANDING UNLAWFULNESS IN CRIMINAL LAW}

\author{
Uldis Krastinšs, Dr. habil. iur. \\ Latvijas Universitātes Juridiskās fakultātes \\ Krimināltiesisko zinātṇu katedras profesors
}

\begin{abstract}
Summary
The article provides an analysis of unlawfulness as one of the features pertaining to the common element of a criminal offence, and draws the distinction between unlawfulness and the constituent elements of a criminal offence.

An opinion has been expressed that linkage of act (failure to act) to the violation of specific provisions regarding protection and precaution in the disposition of a complex criminal offence does not influence the form of guilt in the actual criminal offence.

The author proposes an idea that the existence of a complex criminal offence has been determined by the significance of the object (interest) of the endangerment, the character of the harmful manifestation and other objective circumstances.
\end{abstract}

Atslēgvārdi: prettiesiskums, noziedzīga nodarījuma sastāvs, vaina, salikta sastāva noziedzīgs nodarījums.

Keywords: unlawfulness, constituent element of a criminal offence, guilt, complex criminal offence.

\section{Ievads}

Raksta mērḳis ir analizēt prettiesiskumu kā vienu no noziedzīga nodarījuma vispārējā jēdziena pazīmēm, tā būtību un nozīmi krimināltiesībās. Tiek risināts jautājums par prettiesiskuma un noziedzīga nodarījuma sastāva pazìmju atšḳirībām, kā arī izteikts viedoklis, ka prettiesiskums neietekmē vainas risinājumu salikta sastāva noziedzīgos nodarījumos.

\section{Prettiesiskums un vaina noziedzīgā nodarỉjumā}

Noziedzīga nodarījuma vispārējais jēdziens un tā pazīmes ir dotas Krimināllikuma Vispārīgās daḷas 6. panta pirmajā daḷā: "Par noziedzīgu nodarījumu atzīstams ar nodomu (tīši) vai aiz neuzmanības izdarīts kaitīgs nodarījums 
(darbība vai bezdarbība), kurš paredzēts šajā likumā un par kura izdarīšanu draud kriminālsods."1

Krimināllikuma 6. panta pirmajā daḷā teiktais nozīmē to, ka kriminālatbildība iestājas, ja pastāv šādi Krimināllikumā reglamentēti nosacījumi: 1) ir konstatēts kaitīgs nodarījums (darbība vai bezdarbība); 2) darbība vai bezdarbība atbilst Krimināllikumā (turpmāk - arī KL) paredzēta konkrēta noziedzīga nodarījuma sastāva pazīmēm; 3) darbībai vai bezdarbībai ir tāda kaitīguma pakāpe, kas raksturīga noziedzīgam nodarījumam salīdzinājumā ar citiem tiesībpārkāpumiem; 4) persona ir vainīga nodarījumā; 5) ir noteikta sodāmība, tas ir, par attiecīgo noziedzīgo nodarījumu draud kriminālsods (KL 1. panta pirmā daḷa).

Tātad no KL 6. panta 1. panta pirmajā daḷā dotā vispārējā noziedzīga nodarījuma jēdziena satura redzams, ka viena no noziedzìga nodarījuma pazīmēm ir prettiesiskums, kas izteikts ar vārdiem "[..] izdarīts kaitīgs nodarījums (darbība vai bezdarbība), kurš paredzēts šajā likumā un par kura izdarīšanu draud kriminālsods".

Tas nozīmē, ka prettiesiskums tikai kopumā ar citām pazīmēm (darbību vai bezdarbību, kaitīgumu, vainu un sodāmību) raksturo ikvienu noziedzīgu nodarījumu. Savukārt no šì secinājuma izriet nākamais - noziedzīgā nodarījuma jēdziens ir patstāvīgs krimināltiesību institūts un nav identificējams ar noziedzīga nodarījuma sastāvu, jo pēc sava satura un nozīmes ir plašāks salīdzinājumā ar noziedzìga nodarījuma sastāvu.

Abu institūtu būtību nemaina arī tas, ka vairākās Krimināllikuma Sevišḳās dal̦as normās iekḷauta norāde uz darbības prettiesiskumu, piemēram, KL 116. pantā ir paredzēta atbildība par citas personas tīšu prettiesisku nonāvēšanu (slepkavība). Tāda norāde lieku reizi vienīgi apstiprina to, ka tīša citas personas dzīvības atṇemšana ir Krimināllikumā paredzēts noziedzīgs nodarījums, kas nodēvēts par slepkavību, un ir sodāms.

Krimināltiesībās prettiesiskums noziedzīgā nodarījumā nozīmē to, ka kaitīga darbība vai bezdarbība konkrētos apstākḷos Krimināllikumā tiek atzīta par noziedzīgu nodarījumu un ir sodāma.

Latvijas pirmskara krimināltiesību profesors P. Mincs par noziedzīga nodarījuma prettiesiskumu rakstīja: "[..] noziedzīgs nodarijums katrā ziṇā ir nepaklausība kādai tiesiskai normai - aizliedzošai vai pavēlošai. Tas ir tas vispārējais kritērijs, kuru var attiecināt uz katru noziedzīgu nodarījumu no tiesiskā viedokḷa. Šis kritērijs ir pilnīgi izsmel̦ošs, un tas loğiski izriet no funkcijas, kas piešḳirta krimināltiesībām vispārējā tiesību sistēmā, tas ir, no tiesiskās kārtības apsardzības ar soda vai soda piedraudējuma palīdzību."2

Prettiesiskums un kaitīgums kā noziedzīga nodarījuma neatņemami kritēriji ir cieši savstarpēji saistīti, jo darbības vai bezdarbības kaitīguma smagums ir viens no nosacījumiem, lai tās atzītu par prettiesiskām ar kriminālsoda piedraudējumu. Var teikt, ka nodarījuma kaitīgums ir prettiesiskuma priekšnosacījums.

Noziedzīga nodarījuma kaitīgums izpaužas kā valsts, sabiedrības, atsevišķu cilvēku kopuma vai indivīda pašu nozīmīgāko interešu apdraudējums tādā mērā, ka pret šo apdraudējumu nepieciešams vērsties ar krimināltiesību represijām.

Kaitīgums pēc savas būtības ir sociāla parādība, kas noteiktā kaitīguma pakāpē kḷūst prettiesiska, ja darbība vai bezdarbība, kas radījusi kaitējumu ar

\footnotetext{
${ }^{1}$ Krimināllikums: LV likums. Pieñemts 17.06.1998. Latvijas Vēstnesis, 08.07.1998., Nr. 199/200.

${ }^{2}$ Mincs P. Krimināltiesību kurss. Vispārējā daḷa. Rīga: TNA, 2005, 70. lpp.
} 
likumu aizsargātām interesēm, Krimināllikumā atzīta par noziedzīgu un kriminālsodāmu.

Iepriekš minētajā saistībā profesore M. Blūma krimināltiesību teorijā ne bez pamata nodarījuma sabiedrisko bīstamību (Krimināllikumā tā vietā lietots kaitīguma jēdziens) un prettiesiskumu izmanto kā kopā saistītus jēdzienus. ${ }^{3}$

Tomēr prettiesiskums un kaitīgums ir noziedzīga nodarījuma atšķirīgi institūti. Noziedzīga nodarījuma jēdziens satur pazīmes, kas piemìt ikvienam Krimināllikuma Sevišķajā daḷā paredzētam noziedzīgam nodarījumam. Savukārt noziedzīga nodarījuma sastāvs, kas paredzēts kādā Krimināllikuma Seviškāà daḷas pantā vai tā daḷa (punktā), konkretizē noziedzīga nodarỉjuma vispārējās pazìmes, norādot uz konkrēta noziedzīga nodarījuma objektīvajām un subjektīvajām pazīmēm. Noziedzīga nodarījuma sastāvs kā kriminālatbildības pamats nostiprināts KL 1. panta pirmajā daḷā.

Krimināltiesību teorijā ar noziedzīga nodarījuma sastāvu (corpus delicti), neiedziḷinoties atsevišķu autoru formulējuma niansēs, saprotam Krimināllikumā paredzēto visu objektīvo un subjektīvo pazīmju kopumu, kas nepieciešams, lai kādu darbību vai bezdarbības aktu atzītu par noteikta veida noziedzīgu nodarījumu.

Analizējot Krimināllikuma Sevišķajā dal̦ā paredzēto konkrēto noziedzīgo nodarìjumu objektīvās puses un subjektīvās puses pamatpazīmes, kā arī papildu pazìmes, to skaitā neatrodam prettiesiskumu.

Prettiesiskums nav noziedzīga nodarījuma objekts. Ar nodarījuma objektu krimināltiesībās saprotam valsts, sabiedrības, atsevišķu cilvēku grupu un indivīdu valsts aizsargātās intereses, kuras apdraud noziedzīgs nodarījums.

Noziedzīga nodarījuma objekta apdraudējums var izpausties, iedarbojoties uz nodarỉjuma priekšmetu, radot tam reālu kaitējumu vai draudot tādu nodarìt.

Tātad tiesību normu, kas satur kādu aizliegumu un veido prettiesiskumu, nav pamata uzskatīt arī par konkrēta noziedzīga nodarījuma priekšmetu. Ar noziedzīga nodarỉjuma priekšmetu saprotam cilvēka ārējā pasaulē objektīvi eksistējošu lietu, pret kuru tieši vērsts kaitīgs nodarījums (darbība vai bezdarbība), un līdz ar to tiek apdraudēts noziedzīga nodarījuma objekts.

Tiesību norma ir konstants juridisks faktors, kas jāievēro, kamēr vien tā ir spēkā; Krimināllikumā paredzētajos gadījumos par tās neievērošanu tiek piedraudēts ar kriminālsodu vai citiem piespiedu ietekmēšanas lìdzekḷiem. Tiesību normas pārkāpšanas gadījumā tai nekāds kaitējums netiek nodarīts, tāpēc tās pastāvēšana netiek apdraudēta.

Šajā sakarībā vācu filozofs G. V. F. Hēgelis (Hegel) (1770-1831) ir teicis, ka nekāds noziegums nav spējis iznīcināt tiesības, bet tas spēj likt šķēršlus tiesību visvarai, un tieši tāpēc noziegumam pretstatā ir sods, kas šajā gadījumā uzstājas kā noliegums - noziegums noliedz tiesības - sods noliedz noziegumu. ${ }^{4}$

Prettiesiskuma norobežošanu no noziedzīga nodarījuma objektīvās puses pazīmēm savā 1902. gadā izdotajā grāmatā precīzi raksturojis izcilais krievu kriminologs, krimināltiesību teorētiķis Nikolajs Tagancevs (Николай Степанович Таганиев, 1843-1923). Viņš rakstījis - ja ar noziedzīga nodarījuma sekām saprot pašas tiesību normas apdraudējumu kopā ar aizsargājamo interesi, tad tādas

\footnotetext{
${ }^{3}$ Blūma M. Apstākḷi, kas izslēdz sabiedrisko bīstamību un prettiesiskumu. Mācību līdzeklis. LVU, 1976.

${ }^{4}$ Гегель Г. В. Ф. Философия права. Москва: Наука, 1990, с. 145.
} 
ideālas sekas piemīt ikvienam noziedzīgam nodarījumam, un tad šì pazìme zaudē jebkādu jēgu. ${ }^{5}$

Prettiesiskums nav arī noziedzīga nodarījuma subjektīvās puses pazīme. Ar noziedzīga nodarījuma subjektīvo pusi saprotam vainīgās personas (nodarījuma subjekta) psihisko darbību, kas tieši saistīta ar viņas izdarīto (nodarījuma objektu un objektīvo pusi), un tā apvieno vienotā veselā personas psihiskās darbības intelektuālos un gribas procesus.

Atbilstoši Krimināllikuma 9. un 10. pantam prettiesiskums nav ne nodoma, ne neuzmanības kā vainas formas pazīmju skaitā. Prettiesiskums ar personas psihisko darbību var tikt risināts tikai attiecībā uz likuma vai kāda saistoša noteikuma esamību vai tā satura zināšanu.

Krimināltiesībās par vispārpieņemtu tiek atzīts princips, ka likuma vai saistošā noteikuma nezināšana personu neatbrīvo no atbildības par izdarīto noziedzīgo nodarījumu, pastāvot iespējai ar tiem iepazìties. Tātad likuma vai cita normatīvā regulējuma attaisnojama nezināšana risināma juridiskās kḷūdas ietvaros.

M. Leja ir rakstijis, ka "[..] princips "likuma nezināšana neatbrīvo no atbildỉbas” darbojas neierobežoti. Izņēmums no šī principa iespējams tikai tad, ja rīcību, kas ir noziedzīga, persona maldīgi uzskatījusi par tiesisku, turklāt tikai tad, ja šāda maldība nav bijusi novēršama [..]"6.

Tā kā prettiesiskums nav noziedzīga nodarījuma sastāva pazīme, tad attaisnojamas juridiskās kḷūdas gadījumā nav runas par noziedzīga nodarījuma sastāva neesamību, bet ir jāatzīst, ka personas rīcībā nav prettiesiskuma kā noziedzīga nodarījuma pazìmes un tāpēc, pamatojoties uz KL 6. panta pirmo daḷu, nav pamata viņas saukšanai pie kriminālatbildības.

Kas attiecas uz kḷūdu (maldību) krimināltiesībās, tad jāatzīmē, ka Krimināllikumā par to nekas nav teikts, tāpēc krimināltiesību teorijā iespējami dažādi apsvērumi gan par faktisko, gan juridisko kḷūdu, nonākot atsevišḳos gadijumos pat pie secinājuma, ka sarežğìti ir ne tikai krimināltiesību teorijā, bet arī tiesu praksē norobežot juridisko no faktiskās kḷūdas vai otrādi. ${ }^{7}$

Manuprāt, abu veidu kḷūdas ir nepārprotami jānorobežo, jo katrai no tām ir sava nozīme un arī juridiskās sekas. Norobežošanas pamatā ir jāliek atziņa, ka faktiskā kḷūda attiecas tikai uz konkrētā noziedzīga nodarījuma sastāva pazīmēm, bet juridiskā kḷūda risināma personas psihiskās attieksmes aspektā attiecībā uz prettiesiskumu noziedzīgā nodarījumā.

Kas attiecas uz kriminālatbildību izslēdzošiem apstākḷiem, tad personas darbība nav ne kaitīga, ne prettiesiska.

\section{Salikta sastāva noziedzīgs nodarỉjums un prettiesiskums}

Viens no noziedzīga nodarījuma salikta sastāva veidiem ir gadījums, kad noziedzīga nodarījuma sastāva konstatēšanai atsevišķi ir jānoskaidro vainīgās personas psihiskā attieksme pret darbỉbu vai bezdarbību un pret kaitīgajām sekām, ja pret darbību vai bezdarbību tā izpaudusies nodoma formā, bet pret kaitīgajām sekām - kā neuzmanība.

5 Таганцев Н. С. Русское уголовное право. Часть общая. Том 1. Тула: Автограф, 2001, с. 145.

${ }^{6}$ Leja M. Juridiskās kḷūdas tiesiskās sekas krimināltiesībās. Jurista Vārds, 01.09.2018., Nr. 2, 19. lpp.

7 Leja M. Princips "likuma nezināšana neatbrīvo no atbildības" krimināltiesībās. Jurista Vārds, 22.08.2017., Nr. 35. 
Tas nozìmē, ka pret darbību vai bezdarbību personas psihiskā attieksme jāvērtē pēc formāla sastāva noziedzīgā nodarījuma nosacījumiem, un tā izpaužas kā nodoms (tī̌si) atbilstoši KL 9. panta otrajai daḷai, kurā pateikts, ka noziedzīgs nodarījums atzīstams par izdarītu ar tiešu nodomu, ja persona apzinājusies savas darbības vai bezdarbības kaitīgumu un to apzināti veikusi vai pieḷāvusi. Tātad pirmajā gadījumā tā ir darbība, bet otrajā - bezdarbība. Attiecībā uz kaitīgajām sekām personas psihiskā attieksme izpaužas kā neuzmanība noziedzīgas pašpal̄āvības vai noziedzīgas nevērības veidā, kuru nosacījumi formulēti KL 10. panta otrajā un trešajā daḷā.

Tā kā Krimināllikuma 8. panta pirmā dal̦a paredz tikai divas vainas formas nodomu (tīši) vai neuzmanību, tad logiski, ka ir nepieciešams noteikt, ar kādu vainas formu kopumā tiek izdarīts salikta sastāva noziedzīgs nodarījums.

Tā kā Krimināllikumā jautājums par kopējo vainas formu salikta sastāva noziedzīgos nodarījumos vēl joprojām nav atrisināts, tad krimināltiesību teorijā tiek pausti atšķirīgi viedokḷi par vainas formu dažos salikta sastāva noziedzīgos nodarījumos, ${ }^{8}$ bet tiesu praksē, konstatējot neuzmanību attiecībā uz kaitīgajām sekām, atzīst, ka noziedzīgs nodarījums izdarīts aiz neuzmanības.

Tieslietu ministrija 2014. gadā Krimināllikuma grozījumu projektā bija iestrādājusi priekšlikumu - salikta sastāva noziedzīgu nodarījumu ar atšķirīgu saliktu vainas formu atzìt par izdarītu ar nodomu, taču Saeimas Juridiskā komisija to neatbalstīja un nevirzīja izskatīšanai Saeimas plenārsēdē. ${ }^{9}$

Tātad jautājums par kopējo vainas formu salikta sastāva noziedzīgos nodarījumos Krimināllikumā nav reglamentēts. Atzīmēšu, ka Krimināllikuma Sevišḳās daḷas komentāru 2019. gada izdevuma papildinātās otrās un trešās daḷas autori ${ }^{10}$ salikta sastāva noziedzīgus nodarījumus ar atşkirīgu vainas formu uzskatījuši par izdarīiem ar nodomu.

Nesakārtotība Krimināllikumā un atškirīgie viedoḳ̣i krimināltiesību teorijā jautājumā par vainas formu salikta sastāva noziedzīgā nodarījumā nav šķērslis, lai risinātu problēmu par prettiesiskuma ietekmi uz vainas formu salikta sastāva noziedzīgos nodarījumos.

\section{Prettiesiskuma ietekme uz vainas formu noziedzīgā nodarijumā}

Latvijas krimināltiesībās cita cilvēka dzīvības neatḷauta atṇemšana tiek atzīta par noziedzīgu nodarījumu. Kriminālatbildība par tādu nodarījumu krimināllikumos vienmēr ir bijusi reglamentēta atkarībā no tā, vai tā atṇemta ar nodomu (tīši) vai aiz neuzmanības. Krimināllikumā ar nodomu izdarīta dzīvības atņemšana tiek dēvēta par slepkavību (KL 116. pants), bet aiz neuzmanības - nonāvēšana aiz neuzmanības (KL 123. pants). Tātad vainas forma cita cilvēka dzīvības atṇemšanā ir saistīta ar vainīgā psihisko attieksmi pret kaitīgajām sekām - cilvēka nāves faktu.

${ }^{8}$ Krastiņš U. Atgriežoties pie Krimināllikuma 260. panta, bet ne tikai... Jurista Vārds, 25.04.2017., Nr. 18.

9 Sk: https://titania.saeima.lv/LIVS12/saeimalivs12.nsf/webAll?SearchView\&Query=([Title $]={ }^{*} \mathrm{Groz} \% \mathrm{C} 4$ $\%$ ABjumi+Krimin $\%$ C4\%81llikum $\%$ C4\%81*)\&SearchMax=0\&SearchOrder $=4$

10 Krastiņš U., Liholaja V. Krimināllikuma komentāri. Otrā daḷa (IX-XVII nodaḷa). Otrais papild. izd. Rīga: Tiesu namu aǵentūra, 2019, 559. lpp; Krastiņš U., Liholaja V, Hamkova D. Krimināllikuma komentāri. Trešā daḷa (XVIII-XXV nodal̦a). Otrais papild. izd. Rīga: Tiesu namu aǵentūra, 2019, 879. lpp. 
Jautājums par vainas formu cilvēka prettiesiskā dzīvības atṇemšanā krimināltiesībās it kā būtu atrisināts. Taču, kas attiecas uz nonāvēšanu aiz neuzmanības, tad sarežğỉjumi gan likuma izpratnē, gan krimināltiesību teorijā un praksē ir radušies tāpēc, ka laika gaitā Krimināllikumā arvien vairāk tiek iekḷauti noziedzīga nodarījuma sastāvi, kuros kaitīgās sekas aiz neuzmanības tiek saistītas ar tiešu norādi uz tīšu darbību vai bezdarbību, kas šìs kaitīgās sekas izraisījusi.

Salikta sastāva noziedzīgā nodarījumā darbība vai bezdarbība pēc savas juridiskās nozīmes var būt visai atšķirīga. Šādā noziedzīgā nodarījumā tîši izdarītā darbība vai pieḷautā bezdarbība var nebūt kriminālā kārtā sodāma kā patstāvīgs noziedzīgs nodarījums, kā arī tā var būt kā patstāvīgs noziedzīgs nodarỉjums vai arī var būt administratīvi sodāms tiesībpārkāpums.

Piemēram, Krimināllikuma 268. panta pirmajā daḷā noteikta atbildība par gaisa vai ūdens transportlīdzekḷa, izņemot mazgabarìta transportlīdzekḷus, sagrābšanu uz zemes, ūdeņos vai lidojumā. Tas ir patstāvīgs tīšs noziedzīgs nodarījums. Šā panta otrajā daḷā iekḷauts šā nodarījuma kvalificējošs apstāklis - ja panta pirmajā dạ̦ā paredzētās darbības izraisijjušas avāriju vai citas smagas sekas. Tātad ir veidots salikta sastāva noziedzīgs nodarījums, kurā kaitīgās sekas aiz neuzmanības saistītas ar kriminālsodāmu nodarỉjumu.

Krimināllikuma 260. pantā ir paredzēta atbildība par ceļu satiksmes vai transportlīdzekḷu ekspluatācijas noteikumu pārkāpšanu, saistot to ar nosacijumu, ka tāda darbība vai bezdarbība izraisijjusi šajā pantā paredzētās sekas aiz neuzmanības - miesas bojājumus vai cilvēka nāvi. Tādā noziedzīgajā nodarījumā darbība vai bezdarbỉba, kas izpaudusies ceḷu satiksmes noteikumu vai transportlīdzekḷu ekspluatācijas noteikumu pārkāpšanā, pati par sevi ir sodāma administratīvā kārtā, bet tā (darbība vai bezdarbība), ar kuru tiek pārkāpti minētie noteikumi, tiek kriminalizēta.

Jautājumam par kopējo vainas formu salikta sastāva noziedzīgos nodarïjumos esmu veltīis daudz uzmanības, vairākās publikācijās paužot viedokli: tā kā darbība (bezdarbība), ar kuru pārkāpti cel̦u satiksmes vai transportlīdzekḷu ekspluatācijas noteikumi, ir tîša, tad, kaut arī kaitīgās sekas ir izraisìtas aiz neuzmanības, kopējā vainas forma tādā nodarījumā ir nodoms. ${ }^{11}$

Publiskajā telpā nu ir izteikts viedoklis, ka vainas formu salikta sastāva noziedzīgā nodarījumā ietekmē nosacījums par darbības vai bezdarbības saistī̌šnu noziedzīga nodarījuma aprakstā (dispozīcijā) ar konkrētu aizsardzības vai piesardzības noteikumu pārkāpšanu. ${ }^{12}$

Tātad runa ir par to, ka īpašā normā nonāvēšana aiz neuzmanības, par ko atbildība paredzēta, piemēram, KL 123. pantā, ja tā tiek saistīta ar kādu konkrētu administratīvi sodāmu tiesībpārkāpumu, tad Krimināllikumā, paredzot salikta sastāva noziedzīgu nodarījumu, tas tiek atzīts par izdarìtu ar nodomu (tī̌si). Tātad prettiesiskums, par ko liecina norāde uz konkrētu noteikumu pārkāpumu, ietekmē vainas formu noziedzīgā nodarījumā.

Iepriekš jau esmu izteicis savu viedokli par to, ka prettiesiskums nav noziedzīga nodarïjuma sastāva pazīme, tas neattiecas ne uz noziedzīga nodarïjuma objektu vai nodarījuma priekšmetu, ne arī uz vainas formu noziedzīgā nodarījumā.

${ }^{11}$ Krastiņš U. Komplicēta noziedzīga nodarijuma teorētiskie aspekti. Administratīvā un Kriminālā Justīcija, 2017, Nr. 3, 24.-31. lpp.; Krastiņš U. 2017, Nr. 18.

12 Baumanis J. Krimināllikuma blanketajā normā paredzēta noziedzīga nodarījuma vainas forma. Jurista Vārds, 2020, Nr. 44, 25.-30. lpp. 
Krimināllikuma Sevišḳās daḷas panta dispozīcijās norādei uz konkrētu aizsardzības vai piesardzības noteikumu pārkāpumu (prettiesiskums) saistību ar vainu noziedzīgā nodarījumā ir tikai tāda nozīme, ka darbība (bezdarbība) un kaitīgās sekas aiz neuzmanības tiek pārceltas uz kādu konkrētu personas darbības jomu, kurā gan darbība (bezdarbība), gan kaitīgās sekas izpaužas ar īpaši augstu kaitīguma pakāpi.

Tas nozīmē, ka ir bijusi nepieciešamība stingrāk aizsargāt kādu apdraudēto interesi, kā arī norādìt uz personas rīcības izpausmes paaugstināto kaitīgumu. Darbības vai bezdarbības nozīmīguma reglamentācija personas konkrētā darbības vai bezdarbības jomā cita starpā norāda arī uz nepieciešamību personai būt jo īpaši uzmanīgai un piesardzīgai.

Atbilstoši iepriekš minētajiem apsvērumiem Krimināllikuma Sevišķajā daḷā likumdevējs ir iekḷāvis salikta sastāva noziedzīgu nodarījumu sastāvus, izdarot izṇēmumu no KL 123. panta, kurā atbildība noteikta par nonāvēšanu aiz neuzmanības.

Piemēram, KL 260. panta trešajā daḷā paredzēta atbildība par ceḷu satiksmes noteikumu vai transportlīdzekḷu ekspluatācijas noteikumu pārkāpšanu, ja to izdarījusi persona, kas vada transportlīdzekli, un ja tā izraisījusi divu vai vairāku cilvēku nāvi (aiz neuzmanības). KL 260. pants iekḷauts Krimināllikuma Sevišķās daḷas XXI nodaḷā "Noziedzīgi nodarījumi pret satiksmes drošỉbu". Tas nozìmē, ka šì nodarījuma objekts ir ceḷu satiksmes drošības intereses. Sods par tāda noziedzīga nodarījuma izdarī̌̌anu paredzēts brīvības atṇemšanas veidā uz laiku no trim līdz divpadsmit gadiem.

Krimināllikuma 123. panta otrajā daḷā arī noteikta atbildība par nonāvēšanu aiz neuzmanības, ja nonāvētas divas vai vairākas personas. Sods par tādu noziedzīgu nodarījumu paredzēts brīvības atņemšanas veidā uz laiku lìdz pieciem gadiem. KL 123. pants iekḷauts Sevišķās daḷas XII nodaḷā "Nonāvēšana”. Tātad apdraudētā interese ir cilvēka dzīvība (apdraudējuma objekts).

Salīdzinot abos pantos paredzētās sankcijas, redzam, ka par KL 260. panta otrajā dạ̣a paredzēto nodarījumu noteiktā sankcija ir vairāk nekā divas reizes bargāka salīdzinājumā ar KL 123. panta otrajā daḷā paredzēto.

Tāpēc rodas jautājums: kāda ir bijusi vajadzība veidot KL 260. panta trešo daḷu (tas attiecas arī uz citām kaitīgajām sekām, kas minētas šā panta citās daḷās), ja abos gadījumos kaitīgās sekas iestājušās aiz neuzmanības un abos gadījumos noziedzīgie nodarījumi praksē tiek atzīti par izdarīiem aiz neuzmanības?

Ja jau praksē ir tādi divu vai vairāku cilvēku dzīvības atņemšanas gadījumi aiz neuzmanības un KL 123. panta otrajā daḷā paredzētais sods neatbilst izdarītajam, tad kāpēc nepaaugstināt KL 123. panta otrās daḷas sankciju līdz robežai, kāda paredzēta KL 260. panta otrajā daḷā? Lìdz ar to nebūtu vajadzības veidot ippašu normu - KL 260. pantu - un atkristu arī strīdi par to, ar kādu vainas formu izdarīts noziedzīgais nodarījums, kas paredzēts KL 260. pantā. Teiktais attiecas arī uz dažiem citiem Krimināllikuma pantiem, piemēram, uz KL 239. pantu (būvniecības noteikumu pārkāpšana) un KL 240. pantu (ugunsdrošības noteikumu pārkāpšana).

Atzīstot, ka apzināta darbība vai bezdarbība ir tīša, ka salikta sastāva noziedzīgā nodarījumā ir notikusi apdraudējuma objekta maiṇa, norādot uz darbības (bezdarbības) īpašo jomu, jo uz to norāda attiecīgo noteikumu iekḷaušana šo pantu dispozīcijās (prettiesiskums), kā arī sakarā ar to, ka sankcijas bargums tiek ievērojami paaugstināts, ir pamats uzskatam, ka tādi apstākḷi liecina par šāda noziedzīga 
nodarījuma izslēgšanu no KL 123. panta reglamentācijas, veidojot salikta sastāva noziedzīga nodarījuma sastāvu, kas uzskatāms par izdarītu ar nodomu, protams, abstrahējoties no strīdiem par vainu dažos salikta sastāva noziedzīgos nodarījumos, tajā skaitā par KL 260. pantā paredzēto.

Rezumējot varu teikt, ka salikta sastāva noziedzīga nodarījuma iekḷaušanas pamats Krimināllikuma Sevišķajā daḷā ir nodarījuma (darbības vai bezdarbības), kaitīgo seku un citu objektīvo apstākḷu paaugstinātais kaitīgums, bet nevis prettiesiskums. Tātad Krimināllikuma Sevišķās daḷas konkrēta panta dispozīcijā paredzēta salikta sastāva noziedzīgā nodarījuma aprakstā iekḷautā norāde uz kādu noteikumu pārkāpšanu (prettiesiskums) nevar ietekmēt kopējo vainas formu noziedzīgā nodarījumā, jo prettiesiskums nav noziedzīga nodarījuma sastāva pazīme.

Norāde uz konkrētu aizsardzības un piesardzības noteikumu pārkāpšanu liecina par personas darbošanos īpašā jomā, piemēram, kādā no tautsaimniecības nozarēm (transportā, būvniecībā, ugunsdrošîbas jomā u. c.

Ja konkrēti par KL 260. pantā paredzēto salikta sastāva noziedzīgo nodarījumu, tad salīdzinājumā ar KL 123. pantu ir mainījies apdraudējuma objekts (aizsargājamā interese), un līdz ar to darbības (bezdarbības) joma, kurā tā tiek realizēta, kā arī negadījumā tiek izmantots paaugstinātas bīstamības objekts, t. i., priekšmets - transportlīdzeklis, kas savukārt norāda uz to, ka darbībai ir vispārbīstams raksturs, jo apdraud ne tikai atsevišķu cilvēku dzīvību, kas raksturīgi KL 123. pantā paredzētajam nodarījumam.

Juridiskajā literatūrā tiek pausta doma, ka salikta sastāva noziedzīgu nodarījumu sastāvu veidošana nav īpaši veiksmīgs konstruktīvs risinājums. Pirmskara laikā sarakstītajā mācību grāmatā (1934) profesors P. Mincs izteica domu: "Ja neuzmanība saistīta ar kādu reglamenta pārkāpšanu, tad visvairāk ir vienkārša noziedzīgu nodarījumu kumulācija, ${ }^{13}$ kuru sodāmībai ir jābūt noteiktai pēc vispārējiem likumiem "par kopỉbu" un tikai."14

Tāds princips tad arī bija realizēts Latvijas 1933. gada Sodu likumā. Šā likuma 437. pantā paredzētais noziedzīgais nodarījums formulēts šādi: "Kas aiz neuzmanības nonāvējis [..]"; Sodu likuma 399. panta dispozīcijā teikts: "Kas nav izpildījis likuma vai saistoša noteikuma nosacỉjumus par paškustīgas mašīnas vai velosipēda lietošanu [..."15 Saprotams, ka iepriekš minētais risinājums Latvijas pašreizējā tiesību sistēmā nav iespējams, jo Sodu likuma 399. pantā paredzētais nodarījums ir kriminālpārkāpums, tātad kriminālsodāms nodarījums, bet saskaṇā ar Administratīvo pārkāpumu likumu - administratīvi sodāms tiesībpārkāpums.

Arī to ievērojot, Krimināllikumā veidoti salikta sastāva noziedzīgi nodarījumi, jo noziedzìgu nodarījumu kopỉbu nevar veidot administratīvais tiesībpārkāpums savienojumā ar kriminālsodāmu nodarījumu.

${ }^{13}$ Kumulācija [lat. cumulatio - sakopošana]. Svešvārdu vārdnīca J. Baldunčika redakcijā. Rīga: Jumava, 1999, 413. lpp.

14 Mincs P. 2005, 119. lpp.

15 Sodu likums (1936. g. izd.) ar komentāriem. Sastādijjuši: P. Mincs un J. Lauva. Rīga: Valsts tipogrāfijas izdevums, 1936. 


\section{Kopsavilkums}

1. Prettiesiskums ir viena no noziedzīga nodarījuma pazīmēm, kas pateikts Krimināllikuma 6. panta pirmajā dạ̦ā: "Par noziedzīgu nodarījumu atzīstams ar nodomu vai aiz neuzmanības izdarīts kaitīgs nodarijums (darbība vai bezdarbība), kurš paredzēts šajā likumā un par kura izdarīšanu draud kriminālsods."

2. Prettiesiskums nav Krimināllikuma Sevišksajā dạ̦ā paredzēta konkrēta noziedzīga nodarījuma sastāva ne objektīvā, ne subjektīvā pazìme.

3. Tiesību norma ir konstants juridisks faktors, kas jāievēro, kamēr vien tā ir spēkā; Krimināllikumā paredzētajos gadỉjumos par tās neievērošanu tiek piedraudēts ar kriminālsodu vai citiem piespiedu ietekmēšanas līdzekḷiem. Tiesību normas pārkāpšanas gadījumā tai nekāds kaitējums netiek nodarìts, tāpēc tās pastāvēšana netiek apdraudēta.

4. Tā kā prettiesiskums nav noziedzìga nodarījuma sastāva pazīme, tad Krimināllikuma Sevišḳās daḷas normā, veidojot salikta sastāva noziedzīgu nodarỉjumu un kopā ar prettiesisko darbību vai bezdarbību tajā norādot arī nosacijjumu, ka tiek pārkāpti kādi aizsardzības vai piesardzības noteikumi (prettiesiskums), vainas forma noziedzīgā nodarījumā netiek mainīta.

5. Salikta sastāva noziedzịga nodarījuma esību Krimināllikuma Sevišşajā dạ̦ā nosaka darbības (bezdarbïbas) izpausmes kaitīguma raksturs, apdraudējuma objekta (intereses) nozīmīgums un citi objektīvi apstākḷi. Tâds noziedzīgs nodarījums uzskatāms par izdarītu ar nodomu (tî̌is). 